\title{
Within- versus between-country differences in risk attitudes: implications for cultural comparisons
}

\author{
Ferdinand M. Vieider • Thorsten Chmura • Tyler Fisher • \\ Takao Kusakawa • Peter Martinsson • \\ Frauke Mattison Thompson • Adewara Sunday
}

\begin{abstract}
Cultural comparisons enjoy increasing popularity in economics. Since cultural comparison must abandon random allocation to treatments, it is unclear whether differences found between countries can be attributed to country characteristics or are merely driven by differences in subject pools. In experiments in two Chinese cities and at two campuses in Ethiopia, we show that within-country differences are negligible. Differences between the two countries, on the other hand, are large.
\end{abstract}

We are indebted to Haileselassie Medhin, Xiangdong Qin, Shuwen Li, Eva Xie, Jing Yu, and Jiang Chong for help with the translations of questionnaires and the execution of the experiments. All errors remain ours.

F. M. Vieider $(\varangle)$

WZB Berlin, Reichpietschufer 50, Berlin 10675, Germany

e-mail: fvieider@gmail.com

T. Chmura

University of Nottingham Business School, Nottingham, UK

T. Fisher

University of Michigan at Ann Arbor, Ann Arbor, MI, USA

T. Kusakawa

Hiroshima Shudo University, Hiroshima, Japan

P. Martinsson

University of Gothenburg, Göteborg, Sweden

F. Mattison Thompson

Kings College London, London, UK

A. Sunday

University of Cape Town, Cape Town, South Africa 
Keywords Risk attitudes · Cultural comparison $\cdot$ Experimental economics

JEL Classification $\mathrm{C} 18 \cdot \mathrm{C} 90 \cdot \mathrm{D} 80$

\section{Motivation}

The question of culture's influence on behavior is interesting both because it may reveal differences in behavioral patterns previously thought universal, and because of the underlying determinants of behavior a cultural comparison may shed light on. In a provocative recent paper, Henrich et al. (2010) called attention to the scientific shortcomings that derive from constructing theories of behavior exclusively on observations obtained with Western university students. Indeed, the study of cultural differences is enjoying increasing popularity in economics (e.g., Bohnet et al. 2008; Herrmann et al. 2008; Oosterbeek et al. 2004).

There are several papers that compare risk attitudes between countries (Bruhin et al. 2010; Rieger et al. 2011; Weber and Hsee 1998). Although all of these are controlled experiments, cultural studies hold additional pitfalls. The treatment in cultural comparisons consists by definition of the different subject pools from which samples are drawn. Cultural comparisons must thus by necessity abandon one of the elements that make the experimental method so powerful — the random assignment to treatments of subjects drawn from one and the same subject pool. Instead, it is now the subject pool itself that becomes the element of interest. In order to be sure that the effects picked up in a country comparison are really driven by the specific characteristics of a country, it is not sufficient to find differences between countries. We must also make sure that experiments run in different locations within a country produce the same or reasonably close results.

We here address the issue of the extent to which between-country differences in risk attitudes can clearly be ascribed to culture (loosely "a particular form or stage of civilization"). We do not focus on the cultural determinants per se, but rather on whether inferences on some type of cultural effects can be drawn at all. Specifically, it may just be possible that differences observed between countries derive from (observable or unobservable) differences in the subject pool, or that within-country differences are just as large as between-country differences, given that samples are drawn from different subject populations. This objection is an important one, and previous studies have not ruled out this potential explanation.

To address this issue we ran the same experiment in Beijing and Shanghai, China, and at two different campuses in Addis Ababa, Ethiopia. Controlling for observable heterogeneity in the subject pool, differences in risk preferences measured in the two Chinese cities are marginal, and differences between the two campuses in Addis Ababa are inexistent. This indeed points in the direction that giving up random allocation to treatments is not to blame for differences found between countries, at least once one controls for observable subject characteristics. We are also able to show that differences between the two countries are large. These differences should, however, be interpreted with caution, and do, in any case, not constitute the main point of this paper. We will return to this point in the discussion. 
This paper proceeds as follows. Section 2 introduces the experimental method, as well as the theory and econometric estimation techniques. Section 3 presents the results. Section 4 discusses the results and concludes the paper.

\section{Experiment and theory}

\subsection{Experimental method}

\subsubsection{Subjects}

In China, we ran the experiment with 124 students at Jiao Tong University in Shanghai and with 80 students at Beijing Normal University. In Ethiopia, we recruited 83 subjects on the campus of Economics, Management, and Information Sciences, and 62 subjects from a different campus of Addis Ababa University. The campuses were located in different parts of the city. On all four occasions, subjects were recruited through fliers at the university, which featured an email address and a phone number that could be used for registration. The flyer mentioned that we needed people for an experiment on decision processes, and that subjects would be compensated based on their choices, without mentioning any monetary amounts. Table 1 compares the main observable characteristics across universities and countries.

\subsubsection{Tasks}

Subjects were asked to choose between binary monetary prospects and different sure amounts of money (see example in Fig. 1). This task assesses certainty equivalents (CE) of risk prospects, and is a popular task for measuring risk attitudes (Abdellaoui et al. 2011; Bruhin et al. 2010; Sutter et al. 2012). For gains, subjects will typically prefer the prospect for low sure amounts, and switch over to preferring the sure amount as the latter gets larger (this is reversed for losses). The switching point is called a CE, and indicates the certain amount of money that is considered equally good as choosing

Table 1 Observable subject characteristics

\begin{tabular}{|c|c|c|c|c|c|c|c|}
\hline & \multicolumn{3}{|l|}{ China } & \multicolumn{3}{|l|}{ Ethiopia } & \multirow{2}{*}{$\begin{array}{l}\text { China vs. } \\
\text { Ethiopia } t \text { tes }\end{array}$} \\
\hline & Beijing & Shanghai & $t$ test & Campus 1 & Campus 2 & $t$ test & \\
\hline Male & $49 \%$ & $69 \%$ & $p<0.01$ & $74 \%$ & $50 \%$ & $p<0.001$ & $p=0.62$ \\
\hline Age (mean) & 22.9 & 22.5 & $p=0.07$ & 21.9 & 22.4 & $p=0.05$ & $p<0.01$ \\
\hline Economics & $18 \%$ & $10 \%$ & $p=0.10$ & $100 \%$ & $0 \%$ & $p<0.01$ & $p<0.01$ \\
\hline Mathematics & $20 \%$ & $61 \%$ & $p<0.01$ & $0 \%$ & $24 \%$ & $p<0.01$ & $p<0.01$ \\
\hline Natural science & $25 \%$ & $14 \%$ & $p=0.04$ & $0 \%$ & $18 \%$ & $p<0.01$ & $p<0.01$ \\
\hline Humanities & $20 \%$ & $1 \%$ & $p<0.01$ & $0 \%$ & $5 \%$ & $p<0.01$ & $p=0.04$ \\
\hline Social science & $13 \%$ & $2 \%$ & $p<0.01$ & $0 \%$ & $21 \%$ & $p<0.01$ & $p=0.37$ \\
\hline Study other & $5 \%$ & $12 \%$ & $p=0.09$ & $0 \%$ & $32 \%$ & $p<0.01$ & $p=0.19$ \\
\hline$N$ & 80 & 124 & & 83 & 62 & & \\
\hline
\end{tabular}




\begin{tabular}{|c|c|c|c|}
\hline \multirow{10}{*}{ 10IID } & Lottery & $\begin{array}{c}\text { Sure } \\
\text { amount }\end{array}$ & \\
\hline & $\mathrm{O}$ & $\mathrm{O}$ & 3 Birr for sure \\
\hline & $\mathrm{O}$ & $\mathrm{O}$ & 6 Birr for sure \\
\hline & $\mathrm{O}$ & O & 9 Birr for sure \\
\hline & $\mathrm{O}$ & $\mathrm{O}$ & 12 Birr for sure \\
\hline & $\mathrm{O}$ & $\mathrm{O}$ & 15 Birr for sure \\
\hline & O & O & 18 Birr for sure \\
\hline & $\mathrm{O}$ & $\mathrm{O}$ & 21 Birr for sure \\
\hline & $\mathrm{O}$ & $\mathrm{O}$ & 24 Birr for sure \\
\hline & $\mathrm{O}$ & $\mathrm{O}$ & 27 Birr for sure \\
\hline Win 60 Birr if one of the following balls is extracted: & $\mathrm{O}$ & $\mathrm{O}$ & 30 Birr for sure \\
\hline \multirow[b]{4}{*}{ Win 0 Birr if one of the following balls is extracted: } & $\mathrm{O}$ & $\mathrm{O}$ & 33 Birr for sure \\
\hline & $\mathrm{O}$ & O & 36 Birr for sure \\
\hline & $\mathrm{O}$ & $\mathrm{O}$ & 39 Birr for sure \\
\hline & $\mathrm{O}$ & $\mathrm{O}$ & 42 Birr for sure \\
\hline \multirow[t]{5}{*}{56} & $\mathrm{O}$ & $\mathrm{O}$ & 45 Birr for sure \\
\hline & $\mathrm{O}$ & $\mathrm{O}$ & 48 Birr for sure \\
\hline & O & $\mathrm{O}$ & 51 Birr for sure \\
\hline & $\mathrm{O}$ & $\mathrm{O}$ & 54 Birr for sure \\
\hline & $\mathrm{O}$ & $\mathrm{O}$ & 57 Birr for sure \\
\hline
\end{tabular}

Fig. 1 Example of decision task

the prospect. There were a total of 44 such tasks including gains and losses, risk and uncertainty (full instructions in several languages are available for download at www. ferdinandvieider.com/instructions.html). We will restrict our attention to the case of risk (known probabilities) — results for uncertainty are similar and are available upon request. The tasks were always presented in the same order. This was done to reduce the cognitive burden for subjects, as well as to facilitate the administration of a paper and pencil-based experiment across four universities in two countries (computer-based experiments were not an option due to the absence of IT infrastructure and potentially intermittent power supply). A large-scale pilot with 330 subjects testing a total of 6 different orders showed that such a fixed ordering did not result in different results compared to a random ordering of probabilities, or an order in which ambiguity was presented before risk, as well as several other orders (results available upon request). Losses took place from an endowment. Etchart-Vincent and L' Haridon (2011) tested whether this makes a difference and found none. Experiments were run in the teaching language of the university, instructions were translated, back translated, and then compared. Differences were resolved by discussion.

\subsubsection{Incentives}

One randomly selected choice was played out for each subject - the standard procedure in this type of experiment (Baltussen et al. 2012; Bruhin et al. 2010). Payoffs varied between the PPP equivalent in Germany of $€ 4$ (the show-up fee) and $€ 44$. The conversion rate was $4 \mathrm{RMB} / €$ in China and 6 Birr/€ in Ethiopia. These amounts were 
obtained through careful conversion of the monetary prizes used in other countries through purchasing-power-parity.

\subsection{Theory and econometrics}

We model preferences through prospect theory (PT; Tversky and Kahneman 1992), the dominant descriptive theory of decision making under risk today (Barberis 2013; Loomes et al. 2002; Starmer 2000). Risk attitudes are expressed through a value function, $\mathrm{v}(\mathrm{x})$, that is meant to measure the marginal utility of money, and through a weighting function, $w(p)$, mapping probabilities into decision weights, satisfying $w(0)=0$ and $w(1)=1$. For $x>y \geq 0$ or $x<y \leq 0$, a prospect is represented as:

$$
u(\xi)=w^{i}(p) v(x)+\left(1-w^{i}(p)\right) v(y)
$$

where $\mathrm{u}(\xi)$ indicates the utility of prospect $\xi$, and $i$ indicates the decision domain (gains or losses). Mixed prospects $(x>0>y)$ are represented as follows:

$$
u(\xi)=w^{+}(p) v(x)+w^{-}(1-p) v(y)
$$

For the value function, we use an exponential form (using a power function instead does not affect our conclusions):

$$
V(x)= \begin{cases}\frac{1-e^{-\mu x}}{\mu} & \text { if } x \geq 0 \\ -\lambda \frac{1-e^{-v(-x)}}{v} & \text { if } x<0\end{cases}
$$

where $\mu$ indicates the curvature of the value function for gains ( $>0$ concave; 0 linear; $<0$ convex), $v$ curvature for losses ( $>0$ convex, 0 linear; $<0$ concave), and $\lambda$ loss aversion $(>1)$.

For the weighting function, we use a two-parameter function developed by Prelec (1998):

$$
w(p)=\exp \left\{-\beta(-\ln (p))^{\alpha}\right\}
$$

where $\alpha$ indicates probabilistic sensitivity and $\beta$ determines the elevation of the weighting function (a higher value indicating a more depressed function, and thus increased pessimism for gains and increased optimism for losses). Using an alternative twoparameter specification does not affect our conclusions. Single parameter weighting functions, on the other hand, are generally not well suited to fit data from different countries on which no strong prior evidence exists (Vieider et al. 2013). 


\subsubsection{Econometrics}

Following Loomes et al. (2002) and Conte et al. (2011), we allow for two error terms, a Fechner error and a tremble term. The likelihood of choosing the prospect over a given sure amount $S, \Pi(\xi)$, can be indicated as follows:

$$
\Pi(\xi \mid .)=(1-\tau) \phi\left(\frac{u(\xi)-u(S)}{\sigma}\right)+\tau / 2
$$

where $\tau$ indicates tremble, $\sigma$ is the standard deviation of a the normally distributed Fechner error, and $\phi$ indicates the standard normal cumulative distribution function. We estimate the structural model presented above using maximum likelihood techniques. Errors are clustered at the subject level.

\subsubsection{Hypotheses}

We hypothesize that, while large and significant differences exist between countries, differences within countries will be small or non-existent once differences in the observable characteristics of subjects are controlled for.

\section{Results}

Table 2 shows the estimations for the structural model for China, allowing for heterogeneity in parameters by location. The estimates were obtained in regressions controlling for sex, age, and study major (with economics as the missing category). Such controls are indeed essential, since subject characteristics differ significantly between locations. And indeed, we do find significant effects of sex and some study majors, which-given the significant differences in these variables between study locations-would otherwise distort the results. Most parameters can be seen to not differ significantly between Beijing and Shanghai. The one exception to this rule is the elevation parameter for losses, with subjects in Beijing showing more pessimism than subjects in Shanghai.

Table 3 shows the equivalent regression comparing the two capuses in Addis Ababa, Ethiopia. In this instance, we find no difference at all between the two campuses. There are, on the other hand, again some differences in the control variables. For instance, students of the natural sciences tend to be more optimistic than the reference group of economists, which is shown in the more convex value function for losses, as well as the more elevated probability weighting function for gains. This shows once again the importance of controlling for observable characteristics in this sort of comparison exercises.

Showing that there are no (or only small) differences between two locations in the same country, however, is only one part of the story. Indeed, this may well occur because risk attitudes are the same everywhere. To rule this out, Table 4 shows a regression comparing the aggregate results in China to those in Ethiopia. We find highly significant and large differences between the countries. Ethiopi- 
Table 2 Differences between Beijing and Shanghai

\begin{tabular}{|c|c|c|c|c|c|c|c|}
\hline \multirow[t]{2}{*}{$N=204$} & \multicolumn{3}{|c|}{ Value function } & \multicolumn{2}{|c|}{ Weighting gains } & \multicolumn{2}{|c|}{ Weighting losses } \\
\hline & $\mu$ & $v$ & $\lambda$ & $\alpha^{+}$ & $\beta^{+}$ & $\alpha^{-}$ & $\beta^{-}$ \\
\hline \multirow[t]{2}{*}{ Beijing } & 0.005 & 0.002 & -0.159 & -0.009 & -0.078 & -0.077 & $-0.141^{*}$ \\
\hline & $(0.006)$ & $(0.011)$ & $(0.124)$ & $(0.055)$ & $(0.059)$ & $(0.048)$ & $(0.072)$ \\
\hline \multirow[t]{2}{*}{ Mathematics } & 0.000 & 0.014 & 0.038 & 0.042 & -0.096 & 0.021 & -0.129 \\
\hline & $(0.009)$ & $(0.013)$ & $(0.193)$ & $(0.085)$ & $(0.075)$ & $(0.077)$ & $(0.109)$ \\
\hline \multirow[t]{2}{*}{ Natural science } & -0.007 & 0.001 & 0.128 & 0.040 & -0.022 & -0.058 & -0.068 \\
\hline & $(0.011)$ & $(0.013)$ & $(0.228)$ & $(0.085)$ & $(0.080)$ & $(0.067)$ & $(0.103)$ \\
\hline \multirow[t]{2}{*}{ Humanities } & -0.013 & 0.019 & 0.168 & -0.103 & -0.066 & 0.085 & -0.123 \\
\hline & $(0.013)$ & $(0.017)$ & $(0.269)$ & $(0.095)$ & $(0.100)$ & $(0.115)$ & $(0.140)$ \\
\hline \multirow{2}{*}{$\begin{array}{l}\text { Social science } \\
\text { (non-econ) }\end{array}$} & 0.012 & $0.036^{*}$ & -0.026 & -0.035 & -0.076 & -0.040 & $-0.240^{*}$ \\
\hline & $(0.012)$ & $(0.017)$ & $(0.183)$ & $(0.140)$ & $(0.103)$ & $(0.137)$ & $(0.113)$ \\
\hline \multirow[t]{2}{*}{ Study other } & -0.005 & 0.009 & 0.006 & -0.013 & 0.023 & -0.035 & -0.165 \\
\hline & $(0.013)$ & $(0.015)$ & $(0.201)$ & $(0.106)$ & $(0.104)$ & $(0.089)$ & $(0.114)$ \\
\hline \multirow[t]{2}{*}{ Female } & $0.021^{* * *}$ & $0.019^{*}$ & $-0.283^{*}$ & $-0.092^{\#}$ & -0.036 & -0.077 & $-0.162^{* *}$ \\
\hline & $(0.006)$ & $(0.007)$ & $(0.123)$ & $(0.053)$ & $(0.048)$ & $(0.050)$ & $(0.056)$ \\
\hline \multirow[t]{3}{*}{ Age (z-score) } & -0.001 & 0.002 & -0.010 & -0.022 & 0.012 & 0.006 & 0.026 \\
\hline & $(0.003)$ & $(0.003)$ & $(0.052)$ & $(0.019)$ & $(0.022)$ & $(0.019)$ & $(0.027)$ \\
\hline & -0.001 & 0.002 & -0.010 & -0.022 & 0.012 & 0.006 & 0.026 \\
\hline \multirow[t]{2}{*}{ Constant } & $(0.003)$ & $(0.003)$ & $(0.052)$ & (0.019) & $(0.022)$ & (0.019) & $(0.027)$ \\
\hline & $(0.009)$ & $(0.013)$ & $(0.197)$ & $(0.087)$ & $(0.070)$ & $(0.073)$ & $(0.104)$ \\
\hline
\end{tabular}

$* p<0.05 ; * * p<0.01 ; * * * p<0.001 ; \# p<0.1$

ans are more loss averse, are considerably more optimistic for gains, and are clearly less sensitive to probabilistic change for losses compared to our Chinese sample.

Figure 2 shows the weighting functions for gains. The differences are clearly relevant, with Chinese subjects presenting typical aggregate patterns as found in the past (Bruhin et al. 2010), whereas Ethiopians display high levels of optimism. Figure 3 shows the weighting function for losses, and separately includes the functions for Beijing and Shanghai. Again, the Ethiopian function is clearly different from both Chinese functions (although the latter also differ in elevation from each other).

\section{Discussion and conclusion}

The results presented above clearly show that there are fewer and less pronounced differences within a country than between countries. This does not mean, however, that there are no differences within a country - and we do certainly not claim that risk attitudes in a large country like China need to be the same everywhere. It only goes to show that within-country differences are relatively minor compared to between- 
Table 3 Difference between campuses in Addis Ababa

\begin{tabular}{|c|c|c|c|c|c|c|c|}
\hline \multirow[t]{2}{*}{$N=145$} & \multicolumn{3}{|c|}{ Value function } & \multicolumn{2}{|c|}{ Weighting gains } & \multicolumn{2}{|c|}{ Weighting losses } \\
\hline & $\mu$ & $v$ & $\lambda$ & $\alpha^{+}$ & $\beta^{+}$ & $\alpha^{-}$ & $\beta^{-}$ \\
\hline Campus 2 & $\begin{array}{r}-0.012 \\
(0.012)\end{array}$ & $\begin{array}{c}0.001 \\
(0.024)\end{array}$ & $\begin{array}{c}0.063 \\
(0.376)\end{array}$ & $\begin{array}{c}0.075 \\
(0.144)\end{array}$ & $\begin{array}{c}0.161 \\
(0.140)\end{array}$ & $\begin{array}{c}0.065 \\
(0.185)\end{array}$ & $\begin{array}{r}-0.022 \\
(0.137)\end{array}$ \\
\hline Natural science & $\begin{array}{c}0.016 \\
(0.017)\end{array}$ & $\begin{array}{c}0.084^{*} \\
(0.038)\end{array}$ & $\begin{array}{c}1.447^{\#} \\
(0.877)\end{array}$ & $\begin{array}{c}0.038 \\
(0.306)\end{array}$ & $\begin{array}{r}-0.406^{*} \\
(0.186)\end{array}$ & $\begin{array}{r}-0.287 \\
(0.313)\end{array}$ & $\begin{array}{r}-0.326 \\
(0.303)\end{array}$ \\
\hline Humanities & $\begin{array}{c}0.003 \\
(0.013)\end{array}$ & $\begin{array}{r}-0.033 \\
(0.041)\end{array}$ & $\begin{array}{c}0.354 \\
(0.590)\end{array}$ & $\begin{array}{r}-0.230 \\
(0.326)\end{array}$ & $\begin{array}{c}-0.498^{* * *} \\
(0.133)\end{array}$ & $\begin{array}{c}0.044 \\
(0.207)\end{array}$ & $\begin{array}{c}0.141 \\
(0.276)\end{array}$ \\
\hline Social science & $\begin{array}{c}0.018 \\
(0.014)\end{array}$ & $\begin{array}{c}0.014 \\
(0.036)\end{array}$ & $\begin{array}{c}0.149 \\
(0.616)\end{array}$ & $\begin{array}{c}0.017 \\
(0.188)\end{array}$ & $\begin{array}{r}-0.256 \\
(0.171)\end{array}$ & $\begin{array}{c}0.149 \\
(0.234)\end{array}$ & $\begin{array}{c}0.197 \\
(0.260)\end{array}$ \\
\hline Study other & $\begin{array}{c}0.030 \\
(0.022)\end{array}$ & $\begin{array}{c}0.050 \\
(0.060)\end{array}$ & $\begin{array}{c}0.970 \\
(1.234)\end{array}$ & $\begin{array}{r}-0.027 \\
(0.203)\end{array}$ & $\begin{array}{r}-0.402^{\#} \\
(0.220)\end{array}$ & $\begin{array}{r}-0.143 \\
(0.225)\end{array}$ & $\begin{array}{r}-0.026 \\
(0.306)\end{array}$ \\
\hline Female & $\begin{array}{c}0.011 \\
(0.009)\end{array}$ & $\begin{array}{c}0.031 \\
(0.026)\end{array}$ & $\begin{array}{c}0.690^{\#} \\
(0.393)\end{array}$ & $\begin{array}{c}0.022 \\
(0.107)\end{array}$ & $\begin{array}{r}-0.121 \\
(0.085)\end{array}$ & $\begin{array}{r}-0.016 \\
(0.109)\end{array}$ & $\begin{array}{r}-0.124 \\
(0.214)\end{array}$ \\
\hline Age (z-score) & $\begin{array}{c}0.006^{\#} \\
(0.004)\end{array}$ & $\begin{array}{c}0.007 \\
(0.005)\end{array}$ & $\begin{array}{c}0.109 \\
(0.152)\end{array}$ & $\begin{array}{c}0.021 \\
(0.073)\end{array}$ & $\begin{array}{r}-0.037 \\
(0.034)\end{array}$ & $\begin{array}{r}-0.027 \\
(0.058)\end{array}$ & $\begin{array}{c}0.002 \\
(0.043)\end{array}$ \\
\hline Constant & $\begin{array}{l}0.023^{* * *} \\
(0.007)\end{array}$ & $\begin{array}{r}-0.010 \\
(0.012)\end{array}$ & $\begin{array}{l}1.967^{* * *} \\
(0.189)\end{array}$ & $\begin{array}{l}0.735^{* * *} \\
(0.067)\end{array}$ & $\begin{array}{l}0.711^{* * *} \\
(0.065)\end{array}$ & $\begin{array}{l}0.619^{* * *} \\
(0.053)\end{array}$ & $\begin{array}{l}1.097^{* * *} \\
(0.093)\end{array}$ \\
\hline
\end{tabular}

$* p<0.05 ; * * p<0.01 ; * * * p<0.001 ; \# p<0.1$

Table 4 Difference between China and Ethiopia

\begin{tabular}{|c|c|c|c|c|c|c|c|}
\hline \multirow[t]{2}{*}{$N=349$} & \multicolumn{3}{|c|}{ Value function } & \multicolumn{2}{|c|}{ Weighting gains } & \multicolumn{2}{|c|}{ Weighting losses } \\
\hline & $\mu$ & $v$ & $\lambda$ & $\alpha^{+}$ & $\beta^{+}$ & $\alpha^{-}$ & $\beta^{-}$ \\
\hline Ethiopia & $\begin{array}{c}0.012 \\
(0.006)\end{array}$ & $\begin{array}{c}0.012 \\
(0.012)\end{array}$ & $\begin{array}{l}0.875^{* * *} \\
(0.191)\end{array}$ & $\begin{array}{r}-0.027 \\
(0.053)\end{array}$ & $\begin{array}{c}-0.319^{* * *} \\
(0.053)\end{array}$ & $\begin{array}{c}-0.184^{* * *} \\
(0.054)\end{array}$ & $\begin{array}{c}0.120 \\
(0.087)\end{array}$ \\
\hline Natural science & $\begin{array}{c}0.006 \\
(0.007)\end{array}$ & $\begin{array}{c}0.023^{\#} \\
(0.013)\end{array}$ & $\begin{array}{c}0.155 \\
(0.181)\end{array}$ & $\begin{array}{c}0.000 \\
(0.053)\end{array}$ & $\begin{array}{r}-0.107 \\
(0.069)\end{array}$ & $\begin{array}{r}-0.083 \\
(0.054)\end{array}$ & $\begin{array}{r}-0.162 * \\
(0.082)\end{array}$ \\
\hline Humanities & $\begin{array}{c}0.004 \\
(0.010)\end{array}$ & $\begin{array}{c}0.014 \\
(0.014)\end{array}$ & $\begin{array}{r}-0.018 \\
(0.230)\end{array}$ & $\begin{array}{r}-0.173^{*} \\
(0.075)\end{array}$ & $\begin{array}{c}-0.184^{* *} \\
(0.071)\end{array}$ & $\begin{array}{c}0.040 \\
(0.091)\end{array}$ & $\begin{array}{r}-0.141 \\
(0.108)\end{array}$ \\
\hline $\begin{array}{c}\text { Social science } \\
\text { (non-econ) }\end{array}$ & $\begin{array}{l}0.013^{\#} \\
(0.008)\end{array}$ & $\begin{array}{l}0.030^{*} \\
(0.015)\end{array}$ & $\begin{array}{r}-0.043 \\
(0.155)\end{array}$ & $\begin{array}{r}-0.044 \\
(0.110)\end{array}$ & $\begin{array}{r}-0.100 \\
(0.076)\end{array}$ & $\begin{array}{c}0.015 \\
(0.103)\end{array}$ & $\begin{array}{r}-0.153 \\
(0.105)\end{array}$ \\
\hline Study other & $\begin{array}{c}0.018^{\#} \\
(0.011)\end{array}$ & $\begin{array}{c}0.029^{\#} \\
(0.017)\end{array}$ & $\begin{array}{c}0.156 \\
(0.195)\end{array}$ & $\begin{array}{r}-0.026 \\
(0.069)\end{array}$ & $\begin{array}{r}-0.143 \\
(0.109)\end{array}$ & $\begin{array}{r}-0.061 \\
(0.073)\end{array}$ & $\begin{array}{r}-0.156^{\#} \\
(0.084)\end{array}$ \\
\hline Female & $\begin{array}{l}0.019^{* * *} \\
(0.006)\end{array}$ & $\begin{array}{c}0.019 * \\
(0.009)\end{array}$ & $\begin{array}{r}-0.136 \\
(0.122)\end{array}$ & $\begin{array}{r}-0.075 \\
(0.047)\end{array}$ & $\begin{array}{r}-0.070 \\
(0.051)\end{array}$ & $\begin{array}{r}-0.056 \\
(0.046)\end{array}$ & $\begin{array}{c}-0.137^{*} \\
(0.059)\end{array}$ \\
\hline Age (z-score) & $\begin{array}{c}0.003 \\
(0.002)\end{array}$ & $\begin{array}{c}0.005^{\#} \\
(0.003)\end{array}$ & $\begin{array}{r}-0.026 \\
(0.052)\end{array}$ & $\begin{array}{c}-0.009 \\
(0.019)\end{array}$ & $\begin{array}{r}-0.016 \\
(0.018)\end{array}$ & $\begin{array}{r}-0.010 \\
(0.018)\end{array}$ & $\begin{array}{c}0.001 \\
(0.022)\end{array}$ \\
\hline $\begin{array}{l}\text { Constant } \\
\text { (China) }\end{array}$ & $\begin{array}{c}0.007 \\
(0.004)\end{array}$ & $\begin{array}{r}-0.014^{*} \\
(0.007)\end{array}$ & $\begin{array}{l}1.512^{* * *} \\
(0.080)\end{array}$ & $\begin{array}{l}0.805^{* * *} \\
(0.026)\end{array}$ & $\begin{array}{l}0.995^{* * *} \\
(0.047)\end{array}$ & $\begin{array}{l}0.836^{* * *} \\
(0.030)\end{array}$ & $\begin{array}{l}1.002^{* * *} \\
(0.049)\end{array}$ \\
\hline
\end{tabular}

$* p<0.05 ; * * p<0.01$; *** $p<0.001 ; \# p<0.1$ 


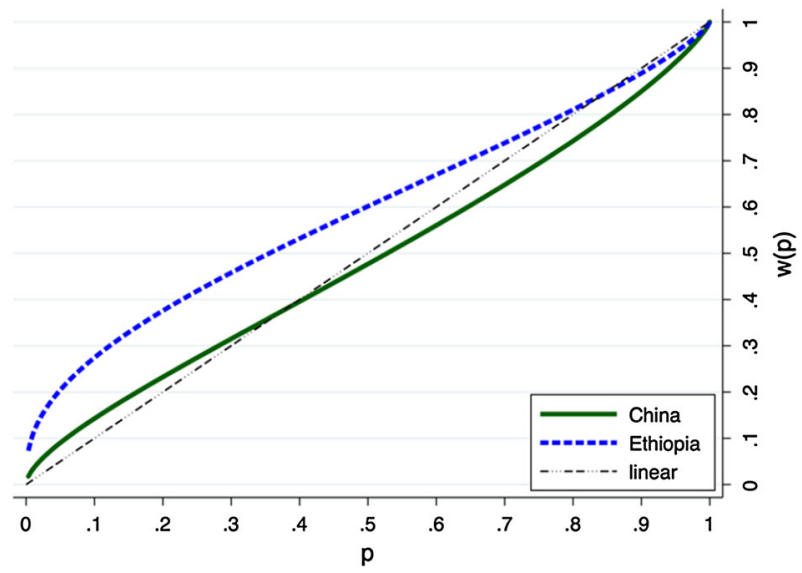

Fig. 2 Weighting functions for gains

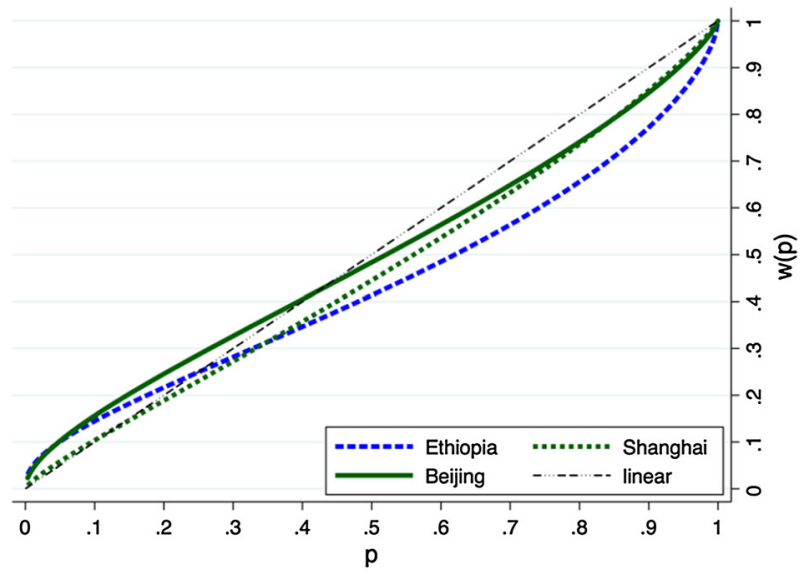

Fig. 3 Weighting for losses

country differences. And importantly, the non-random selection of subject pools seems not to result in differences that one may accidentally attribute to culture once observable characteristics are controlled for.

While the within-country comparisons seem compelling, the juxtaposition of China with Ethiopia may appear arbitrary. Indeed, this comparison was dictated purely by convenience, for reasons of opportunity and cost. As far as the between-country differences are concerned, it has been shown elsewhere (Vieider et al. 2012) that such differences are large- and not just for the two countries we have discussed in this paper. We thus feel confident in concluding that abandoning randomized allocation to treatments cannot account for the differences in risk attitudes found between countries-at least once all visible characteristics of the subject pool have been controlled for. 


\section{References}

Abdellaoui, M., Baillon, A., Placido, L., \& Wakker, P. P. (2011). The rich domain of uncertainty?: Source functions and their experimental implementation. American Economic Review, 101, 695-723.

Baltussen, G., Post, T., van den Assem, M. J., \& Wakker, P. P. (2012). Random Incentive Systems in a Dynamic Choice Experiment. Experimental Economics, 15(3), 418-443.

Barberis, N. C. (2013). Thirty years of prospect theory in economics: A review and assessment. Journal of Economic Perspectives, 27(1), 173-196.

Bohnet, B. I., Greig, F., Herrmann, B., \& Zeckhauser, R. (2008). Betrayal Aversion?: Evidence from Brazil, China, Oman, Switzerland, Turkey, and the United States. American Economic Review, 98, 294-310.

Bruhin, A., Fehr-Duda, H., \& Epper, T. (2010). Risk and rationality: Uncovering heterogeneity in probability distortion. Econometrica, 78(4), 1375-1412.

Conte, A., Hey, J. D., \& Moffatt, P. G. (2011). Mixture models of choice under risk. Journal of Econometrics, 162(1), 79-88.

Dohmen, T., Falk, A., Huffman, D., \& Sunde, U. (2011). The intergenerational transmission of risk and trust attitudes. Review of Economic Studies, 79(2), 645-647.

Etchart-Vincent, N., \& L' Haridon, O. (2011). Monetary incentives in the loss domain and behavior toward risk: An experimental comparison of three reward schemes including real losses. Journal of Risk and Uncertainty, 42, 61-83.

Henrich, J., Heine, S. J., \& Norenzayan, A. (2010). The weirdest people in the world. Behavioral and Brain Sciences, 33, 2-3.

Herrmann, B., Thoeni, C., \& Gaechter, S. (2008). Antisocial punishment across societies. Science, 319(5868), 1362-1367.

Loomes, G., Moffatt, P. G., \& Sugden, R. (2002). A microeconometric test of alternative stochastic theories of risky choice. Journal of Risk and Uncertainty, 24(2), 103-130.

Oosterbeek, H., Sloof, R., \& van de Kuilen, G. (2004). Cultural differences in ultimatum game experiments: Evidence from a meta-analysis. Experimental Economics, 7(2), 171-188.

Prelec, D. (1998). The probability weighting function. Econometrica, 66, 497-527.

Rieger, M. O., Wang, M., \& Hens, T. (2011). Prospect Theory around the World. working paper.

Starmer, C. (2000). Developments in non-expected utility theory: The hunt for a descriptive theory of choice under risk. Journal of Economic Literature, 38, 332-382.

Sutter, M., RützleR, D., \& Trautmann, S. T. (2012). Impatience and uncertainty: Experimental decisions predict adolescent's field behavior. American Economic Review, 103(1), 510-531.

Tversky, A., \& Kahneman, D. (1992). Advances in prospect theory: Cumulative representation of uncertainty. Journal of Risk and Uncertainty, 5, 297-323.

Vieider, F. M., Chmura, T., \& Martinsson, P. (2012). Risk Attitudes, Development, and growth. Macroeconomic evidence from experiments in 30 Countries. Working paper.

Vieider, F. M., Truong, N., Martinsson, P., \& Pham Khanh, N. (2013). Risk preferences and development revisited. Working paper.

Weber, E. U., \& Hsee, C. (1998). Cross-cultural differences in risk perception, but cross-cultural similarities in attitudes towards perceived risk. Management Science, 44(9), 1205-1217. 